\title{
POPULATION-GENETIC CHARACTERISTICS OF DOMESTIC REINDEER OF YAKUTIA BASED ON WHOLE-GENOME SNP ANALYSIS
}

\author{
V.R. KHARZINOVA1, A.V. DOTSEV1, A.D. SOLOVIEVA', V.I. FEDOROV², \\ I.M. OKHLOPKOV 3 , K. WIMMERS ${ }^{4}$, H. REYER ${ }^{4}$, G. BREM ${ }^{1,}$, N.A. ZINOVIEVA ${ }^{1}$
}

${ }^{1}$ L.K. Ernst Federal Science Center for Animal Husbandry, Federal Agency of Scientific Organizations, 60, pos. Dubrovitsy, Podolsk District, Moscow Province, 142132 Russia, e-mail veronika0784@mail.ru (corresponding author), asnd@mail.ru, anastastasiya93@mail.ru,n_zinovieva@mail.ru;

${ }^{2}$ M.G. Sofronov Yakutsk Research Institute of Agriculture, Federal Agency of Scientific Organizations, 23/1, ul. Bestuzheva-Marlinskogo, Yakutsk, Sakha Republic (Yakutia), 677001 Russia, e-mail vfedorov_09@mail.ru;

${ }^{3}$ Institute for Biological Problems of Cryolithozone Siberian Branch of RAS, Federal Agency of Scientific Organizations, 41, pr. Lenina, Yakutsk, Sakha Republic (Yakutia), 677000 Russia, e-mail imo-ibpc@yandex.ru;

${ }^{4}$ Institute of Genome Biology, Leibniz Institute for Farm Animal Biology (FBN), Mecklenburg-Vorpommern, 18196 Dummerstorf, Germany, e-mail wimmers@fbn-dummerstorf.de, reyer@fbn-dummerstorf.de;

5 Institut für Tierzucht und Genetik, University of Veterinary Medicine (VMU), Veterinärplatz, A-1210, Vienna, Austria, e-mail gottfried.brem@vetmeduni.ac.at

ORCID:

Kharzinova V.R. orcid.org/0000-0002-8067-0404

Dotsev A.V. orcid.org/0000-0003-3418-2511

Solovieva A.D. org/0000-0003-2628-9554

Fedorov V.I. org/0000-0002-8454-6531

Okhlopkov I.M. org/0000-0002-6227-5216

Wimmers K. orcid.org/0000-0002-9523-6790

Reyer H. orcid.org/0000-0001-6470-0434

Brem G. orcid.org/0000-0002-7522-0708

Zinovieva N.A. orcid.org/0000-0003-4017-6863

The authors declare no conflict of interests

Acknowledgements:

Equipment of the Collective Center Agricultural Animals' Bioresources and Bioengineering of the L.K. Ernst Federal Science Center for Animal Husbandry was used in the study

Supported financially by Russian Science Foundation (project No. 14-36-00039)

Received May 23, 2017

\section{Abstract}

The Republic of Sakha (Yakutia) is one of the main reindeer herding regions of the Russian Federation. The census population size of domesticated reindeer in the Sakha Republic amounts to more than 156 thousand individuals. Three of the four officially recognized breeds are being bred in Yakutia: the Even, Evenk and Chukotka (Khargin). The analysis of single nucleotide polymorphisms (SNPs) using DNA microarrays (DNA chips) is the useful tool to assess and preserve the biodiversity of this important agricultural species. In the present work, we have used the Bovine SNP50 BeadChip to determine the genotypes and population-genetic characteristics of three domestic reindeer originated from the territory of the Republic of Sakha (Yakutia). Tissue samples (ear skin samples) from reindeer of the breeds Even (EVN, $n=8)$, Evenk $(\mathrm{EVK}, n=11)$ and Chukotka (CHU, $n=7$ ) were used as biological material for the study. The PLINK 1.07 software was used to check the quality of genotyping. For data processing, we used the software PLINK 1.07, Admixture 1.3 , and $\mathrm{R}$ packages diveRsity, VennDiagram with subsequent visualization in the $\mathrm{R}$ packages pophelper and ggplot2. According to the results of quality control, we selected 512 polymorphic SNPs for further analysis. Analysis of Venn-diagrams showed that the reindeer of Even and Evenk breeds have a maximal number of unique polymorphisms (14 SNPs). Eleven unique SNPs were detected in the Chukotka breed. The calculation of basic population parameters revealed that individuals of the Chukotka breed are characterized by higher levels of genetic diversity $\left(\mathrm{H}_{\mathrm{o}}=0.180 \pm 0.011\right.$, $\left.\mathrm{H}_{\mathrm{e}}=0.156 \pm 0.008, \mathrm{~A}_{\mathrm{r}}=1.488 \pm 0.022\right)$ and a higher excess of heterozygotes $\left(\mathrm{F}_{\mathrm{IS}}=-0.124\right)$, compared to Evenk $\left(\mathrm{H}_{\mathrm{o}}=0.161 \pm 0.009, \mathrm{H}_{\mathrm{e}}=0.153 \pm 0.008, \mathrm{~A}_{\mathrm{r}}=1.487 \pm 0.020\right.$, and $\left.\mathrm{F}_{\mathrm{IS}}=-0.047\right)$ and Even $\left(\mathrm{H}_{\mathrm{o}}=0.164 \pm 0.010, \mathrm{H}_{\mathrm{e}}=0.149 \pm 0.008, \mathrm{~A}_{\mathrm{r}}=1.471 \pm 0.021\right.$, and $\left.\mathrm{F}_{\mathrm{IS}}=-0.089\right)$ breeds. The results of multidimensional scaling and the calculation of pairwise genetic distances $\left(\mathrm{F}_{\mathrm{ST}}\right)$ showed the greatest closeness of the breeds Even and Evenk. Admixture analysis revealed a high degree of genetic isolation of each of the studied breeds. However, among the domestic reindeer of Chukotka and Evenk breeds we identified individuals with a mixed genetic origin, which is close to Even genetics. The obtained data will be applied in the development of programs for the conservation and sustainable use of this important animal species.

Keywords: single nucleotide polymorphism, genetic diversity, reindeer breeds 
Reindeer herding is an important component of the economy of the North, Siberia and Far East of Russia [1]. In the Far Eastern Federal district, Republic of Sakha-Yakutia is one of the largest reindeer breeding regions. For indigenous inhabitants of the North of Yakutia domestic reindeer herding is the original lifestyle, which ensures the maintaining traditional livelihoods of representatives of ethnic groups, national traditions and culture. The main competitive advantage of the Sakha Republic is that the whole of its territory belongs to the Far North with a high level of the natural resource economic potential. Yakutia includes taiga-tundra zoogeographical zone, subdivided on the seaside, subarctic and mountain tundra with an unusually rich fauna, suitable for reindeer herding [2]. Reindeer herding is practiced in 20 of the 36 districts and in 1 city district of the Sakha Republic. Out of 3103.2 thousand sq. km of the territory of Yakutia, 2456.5 thousand sq. km or $79.2 \%$ are owned by the reindeer farms [3].

Until 90-ies of the last century, Yakutia consistently held third place in the Russian Federation for the number of domesticated reindeer (361 thousand heads) after Chukotka (491 thousand heads) and Yamal-Nenets Autonomous districts (490.5 thousand heads) [3]. Since the early 1990s, the disruption of the large farms into small ones, reduction of industrial reindeer husbandry and the decline of production and economic indicators of the industry, led to a decrease in the number of reindeer [1]. However, due to the implementation of a number of Government Regulations [4], the Presidential Program [5] and State Programs [6, 7], long-term decline in the number of domestic reindeer was suspended, and by the end of 2016, their number in the Sakha Republic amounted to more than 156 thousand heads [3].

Three of the four officially recognized breeds of reindeer are bred in Yakutia - Even (bred in the twelve districts is mountain-taiga, tundra and foresttundra zones), Evenk (bred in nine regions of the taiga and tundra zones) and Chukotka (Khargin, bred only on the territory of the Nizhnekolymsk ulus). As of January 1, 2015, the number of deer of the above-mentioned breeds was 89913, 41774 and 20750 animals, respectively, which is of 59.0, 27.4 and $13.6 \%$ of the total reindeer population in Yakutia [8, 9]. The deer of Even breed are animals of meat-transport body type with long and relatively elongated body. The body weight of adult males and females is 135-145 kg and 91-110 kg, respectively [9]. The animals of Evenk breed also have a meat-transport body type. Individuals of this breed are characterized by the largest sizes, the higher body weight and good loading capacity. Animals of this breed are long-legged and have elongated body, which provides the best working qualities. The average body weight of adult males is $140-170 \mathrm{~kg}$ and females at the age of 5.5 years are 108-120 kg [9]. Reindeer of Chukotka breed have meat body type and are not specially adapted for transport purposes [10]. Chukotka reindeer are characterized by early maturity and good growing capacity. The body weight of adult males is around 130-140 $\mathrm{kg}$ and females are 93-96 kg [9].

For further effective use and the maintenance of the domestic reindeer population, and for overcoming the negative effects of decreasing their number, it is necessary to apply modern approaches for assessing and preserving the biodiversity of this important agricultural species. The genetic diversity of reindeer was widely studied using different types of genetic markers: protein polymorphisms [11, 12], mitochondrial DNA [13, 14] and nuclear microsatellites [1518]. Until recently, microsatellites were the most common type of genetic markers to study the genetic drift and evolutionary processes, and to evaluate the differentiation degree and genetic diversity of the populations [19]. However, over the last decade, the development and improvement of high-performance meth- 
ods of genotyping single-nucleotide polymorphisms (SNPs) led to a revolution in their application as molecular markers, which can give a precise genetic characterization of populations [20]. A huge number of SNPs in the animal genome (according to various estimates, from three to ten million), allows to select about 100 thousand markers with an average distance between them of $30 \mathrm{~kb}$ [21]. Moreover, every known or expected gene has an average of two SNPs. No other type of genomic differences can provide such density of mapping. In addition to high-density, SNPs are characterized by a very low mutation rate per generation $\left(\sim 10^{-8}\right)$, which makes them excellent markers for studying molecular evolution $[22,23]$.

Practical interest to SNPs has greatly increased in the process of implementing projects aimed to identify the complete nucleotide sequence of agricultural animal species. For example, the sequencing of several complete genomes of cattle revealed the presence of significant numbers of SNPs [24]. Now, their number in the dbSNP database of the National Center for Biotechnology Information (NCBI) of the United States is 73,439,641 [25]. Later, the genomes of several other farm animal species - horses [26], pigs [27], sheep [28] were successfully sequenced.

The demand of this type of molecular markers has led to the development and application of microarrays (DNA chips), which are solid supports of small size (no larger than a microscope slide) with anchored, in a certain manner, short oligonucleotides (in the range of 8-25 bp) or DNA fragments (larger than $100 \mathrm{bp}$ ) [29]. Development of DNA microarrays of different densities for main farm animals species allowed to find a solution for a variety of tasks, such as the evaluation of the variability within and between breeds; determinations of the geographic localization of populations and admixture patterns within populations with different genetic origin; obtaining information concerning evolutionary relationships (phylogenetic trees) and clarifying centers of origin and migration routes; the implementation of gene mapping; creation of DNA banks [30]. To date, the commercial DNA chips designed by Illumina are widely used for the genotyping of nearly all major farm animal species and to obtain information on the genetic diversity for dozens and hundreds of thousands of markers. For non-model species (including reindeer), due to the lack of information about the complete genomes, the development of such kind of an SNP matrix remains unachievable [31]. However, a number of authors have demonstrated the possibility of using such commercial DNA chip (designed for domestic animals) for obtaining information about the genetic diversity and population structure of non-model species [32-37]. In 2015, we published the first evidence of the successful application of DNA chips developed for cattle (Illumina BovineSNP50 BeadChip) and domestic sheep (Illumina OvineSNP50 BeadChip) to study the reindeer [38]. The obtained results served as the basis for further use of the BovineSNP50 BeadChip with the aim of genetic characterization of previously unstudied breeds and populations of this unique representative of the genus Rangifer.

In this paper, we report for the first time a more accurate genetic characterization of the three breeds of domestic reindeer in the Republic of Sakha (Yakutia). The obtained data can be used for improvement of reindeer breeding and husbandry in the region.

The aim of this work was the study of biodiversity of domestic reindeer (Rangifer Tarandus) breeds - the Even, Evenk and Chukotka, which are bred on the territory of Yakutia, using a medium - density BovineSNP50K BeadChip.

Techniques. The study was carried out on the deer of three breeds: Even $($ EVN, FGUP Yukuhashi, $n=8)$, Evenk (EVK, NAOK Taba, $n=11)$ and 
Chukotka-Khargin (CHU, JSC Khatystyr, $n=7$ ). As comparison group, the samples of Yakut wild reindeer (WLD, $n=16$ ) collected during field research in the taiga (TGA, $n=4$ ) and tundra (TUN, $n=12$ ) natural-climatic zones of Yakutia were included in the analysis.

The extraction of genomic DNA from tissue samples (ear samples) was performed using the Nexttec columns (Nexttec Biotechnologie GmbH, Germany) according to the recommendations of the manufacturer. The quality of the isolated DNA was checked by electrophoresis in agarose gel. The DNA concentration in the solution was determined by the measurement of absorption at wavelength $260 \mathrm{~nm}\left(\mathrm{OD}_{260}\right)$. To check the purity of DNA we calculated the ratio of the absorption at wavelengths $260 \mathrm{~nm}$ and $280 \mathrm{~nm}\left(\mathrm{OD}_{260} / \mathrm{OD}_{280}\right)$. Screening of single nucleotide polymorphisms was performed using mediumdensity Bovine SNP50 BeadChip (Illumina, San Diego, CA, USA), including 54609 SNPs.

The PLINK v1.07 software [39] was used to perform quality control of genotyping. The following filters were applied: excluding SNPs genotyped in less than $90 \%$ of individuals (--geno - 0.1); excluding individuals with more than $10 \%$ of missed SNPs of total number of SNPs (--mind - 0.1); excluding loci with minor allele frequency less than 5\% (--maf 0.05); excluding markers not corresponding to the $\chi 2$ criterion for Hardy-Weinberg equilibrium in a population $\left(\mathrm{p} \leq 1 \times 10^{-6}\right)$; deleting SNP with the value of linkage disequilibrium (LD) between pair of single nucleotide polymorphisms equal to $\mathrm{r}^{2}>0.05$ (we used a sliding window of $50 \mathrm{SNPs}$, sliding along in 5 SNP increments). Additionally, to assess the quality of SNP genotyping we used GC Score (quality of reading SNP) and GT Score (the level of clustering SNP) of at least 0.5 (50\%) [40].

To construct Venn diagram, indicating SNPs, which are unique and common to each breed, we used the $\mathrm{R}$ package VennDiagram. To assess genetic diversity in studied reindeer breeds we calculated the values of observed $\left(\mathrm{H}_{\mathrm{o}}\right)$ and expected $\left(\mathrm{H}_{\mathrm{e}}\right)$ heterozygosity, allelic diversity $\left(\mathrm{A}_{\mathrm{r}}\right)$ using the rarefication procedure, the inbreeding coefficient $\left(\mathrm{F}_{\mathrm{IS}}\right)$ [41] and visualized genetic diversity employing the R package diveRsity [42]. Multidimensional scaling (MDS) based on the matrix of distances of the identity-by-state (IBS) was performed in PLINK 1.07 (--cluster, --mds-plot 4). The degree of genetic differentiation of populations was assessed based on pairwise values of $F_{S T}$ [43] calculated in the R package diveRsity [42]. Results of genetic structure of populations and relationships between populations were obtained using the Admixture 1.23 software [44] with subsequent visualization in the $\mathrm{R}$ package pophelper [45].

In data statistical processing, the arithmetic mean $(M)$ and standard errors of mean $( \pm m)$ were calculated.

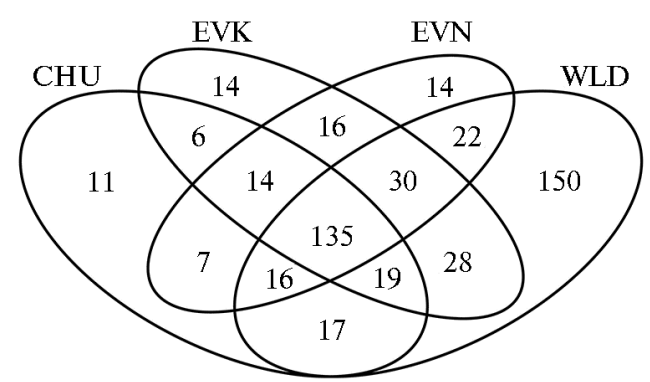

Fig. 1. Venn-diagram of the distribution of unique and common SNPs for studied groups of reindeer (Rangifer tarandus). Breeds of domesticated reindeer: CHU - Chukotka, EVK - Evenk, EVN Even; WLD - population of wild reindeer (Sakha Republic, 2016-2017).
Results. In total, 22807 SNPs passed through the quality control and 512 of them were polymorphic and were used for further analysis. The small number of polymorphic markers is due to the fact that with increasing phylogenetic distances between Bovidae and Cervidae families, the number of polymorphic SNPs decreases, which was also revealed by a drop in the total number of genotyped SNPs (call rate) from 99.54 to $61.19 \%$ (37).

Analysis of genetic diversity in domesticated reindeer (Table 1) 
showed a higher level of observed heterozygosity in the Chukotka reindeer breed $\left(\mathrm{H}_{\mathrm{o}}=0.180 \pm 0.011\right)$. Previously, it was shown that this breed was superior to the Even and Evenk breeds in terms of genetic diversity assessed using microsatellites [18]. Animals of the Evenk breed were characterized by the lowest values of observed heterozygosity $\left(\mathrm{H}_{\mathrm{o}}=0.161 \pm 0.009\right)$. Calculation of rarified allelic diversity $\left(\mathrm{A}_{\mathrm{r}}\right)$ showed no significant differences between the breeds: the values of $\mathrm{A}_{\mathrm{r}}$ ranged from 1.471 in EVN to 1.488 in CHU. All three breeds were characterized by a slight excess of heterozygotes, as evidenced by the negative values of the coefficient of inbreeding $\left(\mathrm{F}_{\mathrm{IS}}\right)$, with a range from $\mathrm{F}_{\mathrm{IS}}=-0.124$ in $\mathrm{CHU}$ to $\mathrm{F}_{\mathrm{IS}}=-0.047$ in $\mathrm{EVN}$.

1. Genetic diversity of three reindeer (Rangifer tarandus) breeds based on single nucleotide polymorphism genotyping (Sakha Republic, 2016-2017)

\begin{tabular}{l|r|l|l|c|c}
\hline \multicolumn{1}{c}{ Breeds } & $n$ & $\mathrm{H}_{\mathrm{O}}(M \pm m)$ & $\mathrm{H}_{\mathrm{e}}(M \pm m)$ & $\mathrm{F}_{\mathrm{IS}}$ & $\mathrm{A}_{\mathrm{r}}(M \pm m)$ \\
\hline CHU & 7 & $0.180 \pm 0.011$ & $0.156 \pm 0.008$ & -0.124 & $1.488 \pm 0.022$ \\
EVK & 11 & $0.161 \pm 0.009$ & $0.153 \pm 0.008$ & -0.047 & $1.487 \pm 0.020$ \\
EVN & 8 & $0.164 \pm 0.010$ & $0.149 \pm 0.008$ & -0.089 & $1.471 \pm 0.021$
\end{tabular}

$\mathrm{N}$ o t e. Breeds of domesticated reindeer: CHU - Chukotka, EVK - Evenk, EVN - Even; $\mathrm{H}_{\mathrm{o}}$ - observed heterozygosity, $\mathrm{H}_{\mathrm{e}}-$ expected heterozygosity, $\mathrm{F}_{\mathrm{IS}}-$ coefficient of inbreeding, $\mathrm{A}_{\mathrm{r}}$ - allelic diversity, calculated using the rarefication procedure.

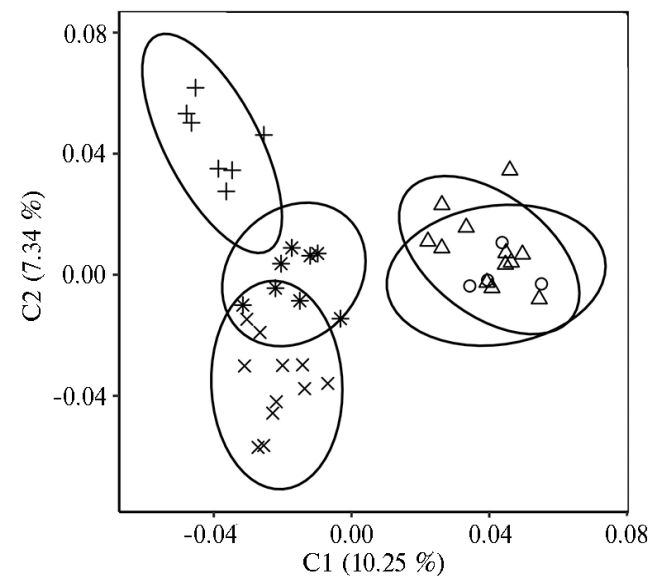

Fig. 2. Graphic representation of results of multidimensional scaling (MDS) of reindeer (Rangifer tarandus) samples, genotyped with Bovine SNP50 BeadChip: + - CHU (Chukotka breed), $\times-$ EVK (Evenk breed), * - EVN (Even breed); 0 and $\Delta-$ taiga and tundra populations of wild reindeer, respectively; $\mathrm{C} 1$ - component $1, \mathrm{C} 2-$ component 2 (Sakha Republic, 2016-2017).

cating their genetic similarity.
A diagram of the location of the studied samples based on SNP analysis using the method of multidimensional scaling (MDS) is presented in figure 2. The first component $(\mathrm{C} 1)$ explained $10.25 \%$ of the total variance and clearly separated domestic and wild populations, while, the second component (C2), explaining about $8 \%$ of the total variability, allowed to differ the domestic reindeer breeds from each other. The individuals of the Even and Evenk breeds were characterized by the greatest genetic closeness with a minor overlapping of breedspecific clusters. The presence of admixed individuals can be explained by the closer geographical location of breeding farms of these breeds. Wild reindeer of the taiga and tundra populations formed a common cluster indi-

2. Differentiation of the studied breeds of reindeer (Rangifer tarandus) by $\mathrm{F}_{\mathrm{ST}}$ index at pairwise comparison, based on SNP genotypes (Sakha Republic, 2016-2017)

\begin{tabular}{|c|c|c|c|c|}
\hline Groups & $\mathrm{CHU}$ & EVK & EVN & WLD \\
\hline$\overline{\mathrm{CHU}}$ & 0.0000 & & & \\
\hline EVK & 0.0953 & 0.0000 & & \\
\hline EVN & 0.0981 & 0.0632 & 0.0000 & \\
\hline WLD & 0.1007 & 0.0659 & 0.0597 & 0.0000 \\
\hline
\end{tabular}

Calculation of $\mathrm{F}_{\mathrm{ST}}$ values at pairwise comparison (Table 2) showed similar trends with the results of the MDS analysis: the lowest value $\left(\mathrm{F}_{\mathrm{ST}}=0.006\right)$ 
was detected between the Even and Evenk breeds confirming their greater genetic closeness. The reindeer of Chukotka breed were equidistant from both breeds: the Even $\left(\mathrm{F}_{\mathrm{ST}}=0.098\right)$ and the Evenk $\left(\mathrm{F}_{\mathrm{ST}}=0.095\right)$; and were the most differentiated from the wild population $\left(\mathrm{F}_{\mathrm{ST}}=0.101\right)$.

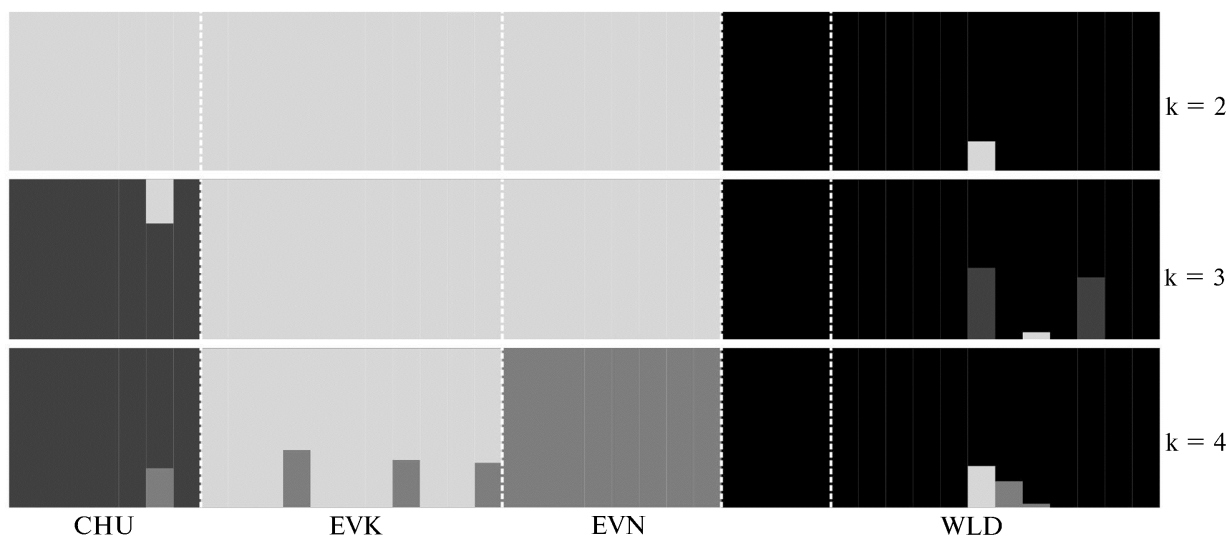

Fig. 2. Genetic structure of studied breeds of reindeer (Rangifer tarandus) based on results of admixture analysis of samples genotyped with Bovine SNP50 BeadChip for the cluster number k from 2 to 4: CHU - Chukotka, EVK - Evenk, EVN - Even; WLD - population of wild reindeer (Sakha Republic, 2016-2017).

Admixture analysis of the genetic structure of the studied reindeer breeds (Fig. 2) for the number of clusters $\mathrm{k}=2$ demonstrated a clear differentiation of domestic breeds from the wild reindeer population. At $\mathrm{k}=3$, the individuals of Chukotka breed formed their own cluster, while animals of the Even and Evenk breeds clustered together. At $\mathrm{k}=4$, each of the investigated breeds formed its own cluster with a high degree of genetic isolation. However, it is necessary to indicate that within the Chukotka and Evenk breeds some animals had an admixed genetic origin, which was closer to EVN breed. Individuals of the wild reindeer population, used as a comparison group, retained their membership in their own cluster at $\mathrm{k}$ from 2 to 4 , although some of them revealed the admixture signals of domesticated reindeer.

Thus, our study showed the successful application of DNA chip designed for cattle to differentiate reindeer breeds from each other and from the wild reindeer, and to assess the genetic structure of breeds.

Numerous publications have demonstrated the successful study of related non-model species using a commercial BovineSNP50K BeadChip, developed for domestic cattle. G.D. Haynes and E.K. Latch [35] gave a description of two representatives of the family Cervidae: mule deer (O. hemionus) and white-tailed deer (O. virginianus). They found that $38.7 \%$ of loci could be genotyped, of which $5 \%(n=1068)$ were polymorphic. R. Kasarda et al. [37] performed the study of two species from the family Cervidae: red deer (Cervus elaphus) and fallow deer (Dama dama). In total, $94.76 \%$ SNPs were successfully genotyped and $5.24 \%$ (1542) of them were polymorphic. Studying the European bison (Bison bonasus), M. Tokarska et al. [46] found 960 polymorphic loci. C. Pertoldi et al. [32] identified 929, 1403 and 1524 polymorphic SNPs in European bison (Bison bonasus; EB) and two subspecies of American bison: the plains bison ( $B$. bison bison; PB) and the wood bison (B. bison athabascae; WB), respectively. Authors showed that SNP genotyping systems developed for domestic species could be effective even in bottlenecked species in which heterozygosity of other markers such as microsatellites may be very low [46, 32]. Along with the study of biodiversity and evolutionary relationships, SNP markers have found application 
for the determination of the parentage verification [47]. Thus, above-mentioned studies clearly showed that SNP genotyping systems developed for domestic species represent powerful tools for genetic analysis in related non-model species

Thus, as the result of our study of single nucleotide polymorphisms using DNA chips, designed for cattle, we gave the population-genetic characterization of three breeds of domestic reindeer - Chukotka (Khargin), Even and Evenk, which are bred in the territory of one of the main reindeer herding regions of Russia - Republic of Sakha (Yakutia). Reindeer herding in this region is connected not only to the agricultural sector, but is an integral part of the lifestyle and culture of indigenous people. The obtained data can be used to develop programs for the conservation and management of this species important for agricultural biodiversity.

\section{REFEREN C ES}

1. Az a rova L.V. Molodoi uchenyi, 2013, 5: 831-833 [in Russ.].

2. Robbek N.S., A b r a mov A.F. Evenskaya poroda olenei Yakutii: myasnaya produktivnost', biologicheskaya i pishchevaya tsennost' [Even reindeer: meat production, biological and nutritional value]. A.D. Reshetnikov [ed.]. Novosibirsk, 2017 [ISBN 978-5-4379-0519-7] [in Russ.].

3. O k o r o k ov A.I. Vestnik Severo-Vostochnogo federal'nogo universiteta imeni M.K. Ammosova, 2013, 10[3]: 36-41 [in Russ.].

4. S y ro v a t s k i i D.I. Dostizheniya nauki i tekhniki APK, 2006, 5: 10-11 [in Russ.].

5. Prezidentskaya programma sotsial'no-ekonomicheskogo razvitiya sela Respubliki Sakha [Yakutiya] na 2002-2006 gody. Utv. rasporyazheniem Prezidenta Respubliki Sakha [Yakutiya] ot 23 dekabrya 2002 goda № 328-RP [The President Program for social and economic development of the Sakha Republic in 2002-2006. Approved by the decree of President of Sakha Republic № 328-RP of December 23, 2002 [Yakutiya]] [in Russ.].

6. Zakon Respubliki Sakha [Yakutiya] ot 11 iyulya 2007 goda, Z № 991-III. O gosudarstvennoi tselevoi programme «Sotsial'no-ekonomicheskoe razvitie sela Respubliki Sakha [Yakutiya] na 2007-2011 gody» [Low of the Sakha Republic Z № 991-III of July 11, 2007 about the State Program of social and economic development of rural areas in Sakha Republic for 2007-2011] [in Russ.].

7. Gosudarstvennaya tselevaya programma «Sotsial'no-ekonomicheskoe razvitie sela Respubliki Sakha [Yakutiya] na 2012-2016 gody». Utv. Rasporyazheniem Pravitel'stva RS [YA] № 1394-r ot 24.12.2011 g. [State Program of social and economic development of rural areas in Sakha Republic for 2012-2016. Approved by the decree of the Government of Sakha Republic № 1394-r of December 24, 2011] [in Russ.].

8. Ale k s e e v E.D. Tekhnologiya kruglogodichnogo izgorodnogo soderzhaniya domashnikh olenei $v$ usloviyakh taezhnoi zony Yakutii. Avtoreferat kandidatskoi dissertatsii [Coral-based technology of all-the-year-round keeping domestic reindeers in taiga zone of Yakutiya. PhD Thesis]. Yakutsk, 2009 [in Russ.].

9. Plemennaya rabota $v$ olenevodstve [Breeding in reindeer herding]. Available http://reindeer.sakhaplem.ru/plemennaya-rabota-v-olenevodstve/. No date [in Russ.].

10. Mukh a chev A.D. Olenevodstvo [Reindeer herding]. Moscow, 1990 [ISBN 5-10-000725-7] [in Russ.].

11. Ro ed K.H. Genetic differences at the transferrin locus in Norwegian semidomestic and wild reindeer [Rangifer tarandus L.]. Hereditas, 1985, 102: 199-206.

12. S h u b i n P.N. Genetics transferrin of European reindeer and moose. Genetics, 1988, 5[1]: 37-41.

13. F l a g s t a d O., R $\varnothing$ ed K.H. Refugial origins of reindeer [Rangifer tarandus L.] inferred from mitochondrial DNA sequences. Evolution, 2003, 57[3]: 658-670.

14. Cronin M.A., M a c N e il M.D., Pat to n J.C. Variation in mitochondrial DNA and microsatellite DNA in caribou [Rangifer tarandus] in North America. J. Mammalogy, 2005, 86: 495-505.

15. B a 11 M.C., Finnegan L., M a n s e a u M., Wils o n P. Integrating multiple analytical approaches to spatially delineate and characterize genetic population structure: an application to boreal caribou [Rangifer tarandus caribou] in central Canada. Conserv. Genet., 2010, 11: 21312143 [doi: 10.1007/s10592-010-0099-3].

16. McDevitt A.D., Mariani S., Hebblewhite M., De Cesare N.J., Morganti ni L., S e ip D., We ckworth B.V., Musiani M. Survival in the Rockies of an endangered hybrid swarm from diverged caribou [Rangifer tarandus] lineages. Mol. Ecol., 2009, 18: 665-679 [doi: 10.1111/j.1365-294X.2008.04050.x].

17. Wils o n G.A., Strobeck C., Wu L., C offi n J.W. Characterization of microsatellite loci in caribou Rangifer tarandus, and their use in other artiodactyls. Mol. Ecol., 1997, 65: 697699 [doi: 10.1046/j.1365-294X.1997.00237.x]. 
18. Kharzi nova V.R., Glad y r' E.A., Fedorov V.I., Romane nko T.M., Shi m it L.D., Layshev K.A., Kalashnikova L.A., Z inovieva N.A. Development of multiplex microsatellite panel to assess the parentage verification in and differentiation degree of reindeer populations [Rangifer tarandus]. Sel'skokhozyaistvennaya biologiya [Agricultural Biology], 2015, 50[6]: 756-765 [doi: 10.15389/agrobiology.2015.6.756eng].

19. Kharzinova V.R., Dotsev A.V., Kramarenko A.S, Layshev K.A., Ro ma ne nko T.M., Solov'eva A.D., De niskova T.E., Kostyunina O.V., B rem G., Zinovieva N.A. Study of the allele pool and the degree of genetic Introgression of semidomesticated and wild populations of reindeer [Rangifer tarandus L., 1758] using microsatellites. Agricultural Biology, 2016, 51[6]: 811-823 [doi: 10.15389/agrobiology.2016.6.811eng] [in Engl.].

20. D e n i s k ova T.E., S e r m y a g i n A.A., B a g i rov V.A., O k h lopkov I.M., G lad y r E.A., I va nov R.V., B re m G., Z i n o veva N.A. Genetika, 2016, 52[1]: 90-96 [doi: 10.7868/S0016675816010021] [in Russ.].

21. Li J., Butler J.M., Tan J., Li n H., Royer S., Ohle r L., Shaler T.A., Hun te r J.M., Pollart D.J., Monforte J.A., B e cker C.H. Single nucleotide polymorphism determination using primer extension and time off mass spectrometry. Electrophoresis, 1999, 20: 1258-1265.

22. C row J.F. Spontaneous mutation as a risk factor. Exp. Clin. Immunogenet., 1995, 12: 121-128.

23. Li W.H., El1sworth D.L., Krushkal J., Chang B.H., Hewett-Emmet D. Rates of nucleotide substitution in primates and rodents and the generation-time effect hypothesis. Mol. Phylogenet. Evol., 1996, 5: 182-187.

24. The Bovine HapMap Consortium Genome-Wide Survey of SNP Variation Uncovers the Genetic Structure of Cattle Breeds. Science, 2009, 324: 528-532.

25. NCBI Resource Coordinators. Database resources of the National Center for Biotechnology Information. Nucleic Acids Research, 2015, 43: 6-17 [doi: 10.1093/nar/gku1130].

26. Wade C.M., Giulotto E., Sigurdsson S., Zoli M., Gnerre S., Imsland F., Lear T.L., Adelson D.L., B a iley E., B e 11 o ne R.R., B lö cker H., D ist l O., Edgar R.C., Garber M., Leeb T., Mauceli E. Genome sequence, comparative analysis, and population genetics of the domestic horse. Science, 2009, 326: 865-867 [doi: 10.1126/science.1178158].

27. Archibald A.L., Bolund L., Churcher C., Fredholm M., Groenen M.A., Harlizius B., Lee K.T., Milan D., Rogers J., Rothschild M.F., Uenishi H., Wang J., Schook L.B., Swine Genome Sequencing Consortium. Pig genome sequence - analysis and publication strategy. BMC Genomics, 2010, 11: 438-442 [doi: 10.1186/1471-2164-11-438].

28. Jiang Y., Xie M., Chen W., Talbot R., Maddox J.F., Thomas F., Chunhua W., Muzny D.M., Yuxiang L., Wenguang Z., Stanton J.-A., Brauning R., Barris W.C., Hourlier T., Bronwen L. Aken B.L., Searle S.M.J., Adelson D.L., Bian C., Cam G.R., Chen Y., Cheng S., DeSilva U., Dixen K., Dong Y., Fan G., Franklin I.R., Fu S., Guan R., Highland M.A., Holder M.E., Huang G., Ingham A.B., Jhangiani S.N., Kalra D., Kovar C.L., Lee S.L., Liu W., Liu X., Lu C., Lv T., Mathew T., McWilliam S., Menzies M., Pan S., Robelin D., Servin B., Townley D., Wang W., Wei B., White S.N., Yang X., Ye C., Yue Y., Zeng P., Zhou Q., Hansen J.B., Kristensen K., Gibbs R.A., Flicek P., Warkup C.C., Jones H.E., Oddy V.H., Nicholas F.W., McEwan J.C., Kijas J., Wang J., Worley K.C., Archibald A.L., Cockett N., Xu X., Wang W., Dalrymple B.P. The sheep genome illuminates biology of the rumen and lipid metabolism. Science, 2014, 344: 1168-1173 [doi: 10.1126/science.1252806].

29. Hacia J.G., Collins F.S. Mutation analysis using oligonucleotide microarrays. J. Med. Genet., 1999, 36: 730-736.

30. Glazko V.I. Farm animals, 2012, 1: 24-29 [in Russ.].

31. Seeb J.E., Carvalho G.R., Hauser L., Naish K., Roberts S., Seeb L.W. Singlenucleotide polymorphism [SNP] discovery and applications of SNP genotyping in nonmodel organisms. Molecular Ecology Resources, 2011, 11: 1-8 [doi: 10.1111/j.1755-0998.2010.02979.x].

32. Pertoldi C., Wyjcik J.M, Tokarska M., Kawałko A., Kristensen T.N., Loeschcke V., Gregersen V.R., Coltman D., Wilson G.A., Randi E., Henryon M., Bendixen C. Genome variability in European and American bison detected using BovineSNP50 BeadChip. Conservation Genetics, 2010, 11: 627-634.

33. Miller J.M., Poissant J., Kijas J.W., Coltman D.W., International Sheep Genomics Consortium. A genome-wide set of SNPs detects population substructure and long range disequilibrium in wild sheep. Molecular Ecology Resources, 2011, 11[2]: 314-322 [doi: 10.1111/j.17550998.2010.02918.x].

34. Ogden R., Baird J., Senn H., McEwing R. The use of cross-species genome-wide arrays to discover SNP markers for conservation genetics: a case study from Arabian and scimitarhorned oryx. Conservation Genetics Resources, 2012, 4: 471-473.

35. Haynes G.D., Latch E.K. Identification of novel single nucleotide polymorphisms [SNPs] in deer [Odocoileus spp.] using the BovineSNP50 BeadChip. PLoS ONE, 2012, 7: e36536 [doi: 
10.1371/journal.pone.0036536].

36. Deniskova T.E., Okhlopkov I.M., Sermyagin A.A., Gladyr' E.A., Bagirov V.A., Sölkner I., Mamaev N.V., Brem G., Zinov'eva N.A. Doklady Akademii nauk, 2016, 469[5]: 625-630 [in Russ.].

37. Kasarda R., Moravcíková N., Židek R., Mészáros G., Kadlečík O., Trakovická A., Pokorádi J. Investigation of the genetic distances of bovids and cervids using BovineSNP50k BeadChip. Arch. Anim. Breed., 2015, 58: 57-63 [doi: 10.5194/aab-58-57-2015].

38. Kharzinova V.R., Sermyagin A. A., Gladyr E.A., Okhlopkov I. M., Brem G., Zinovieva N.A. A study of applicability of SNP chips developed for bovine and ovine species to whole-genome analysis of reindeer Rangifer tarandus. Journal of Heredity, 2015, 106[6]: 758-761 [doi: 10.1093/jhered/esv081].

39. Purcell S., Neale B., Todd-Brown K., Thomas L., Ferreira M.A.R., Bender D., Maller J., Sklar P., de Bakker P.I., Daly M.J., Sham P.C. PLINK: a tool set for whole-genome association and population-based linkage analyses. American Journal of Human Genetics, 2007, 81: 559-575 [doi: 10.1086/519795].

40. Fan J.B., Oliphant A., Shen R., Kermani B.G., Garcia F., Gunderson K.L., Hansen M., Steemers F., Butler S.L., Deloukas P., Galver L., Hunt S., McBride C., Bibikova M., Rubano T., Chen J., Wickham E., Doucet D., Chang W., Campbell D., Zhang B., Kruglyak S., Bentley D., Haas J., Rigault P., Zhou L., Stuelpnagel J., Chee M.S. Highly parallel SNP genotyping. Cold Spring Harb. Symp. Quant. Biol., 2003, 68: 69-78.

41. Hartl D.L., Clark A.G. Principles of population genetics. Sunderland, Massachusetts, 1997.

42. Keenan K., McGinnity P., Cross T.F., Crozier W.W., Prodohl P.A. diveRsity: An R package for the estimation of population genetics parameters and their associated errors. Methods in Ecology and Evolution, 2013, 4: 782-788 [doi: 10.1111/2041-210X.12067].

43. Weir B.S., Cockerham C.C. Estimating F-statistics for the analysis of population structure. Evolution, 1984, 38: 1358-1370.

44. Alexander D.H., Novembre J., Lange K. Fast model based estimation of ancestry in unrelated individuals. Genome Res., 2009, 19: 1655-1664 [doi: 10.1101/gr.094052.109].

45. Francis R.M. pophelper: An R package and web app to analyse and visualise population structure. Molecular Ecology Resources, 2016 [doi: 10.1111/1755-0998.12509].

46. Tokarska M., Marshall T., Kowalczyk R., Wyjcik J.M., Pertoldi C., Kristensen T.N., Loeschcke V., Gregersen V.R., Bendixen C. Effective ness of microsatellite and SNP markers for parentage and identity analysis in species with low genetic diversity: the case of European bison. Journal of Heredity, 2009, 103: 326-332 [doi: 10.1038/hdy.2009.73].

47. Oleński K., Kamiński S., Tokarska M., Hering D.M. Subset of SNPs for parental identification in European bison Lowland-Białowieża line [Bison bonasus bonasus]. Conservation Genetics Resources, 2017, First Online 13 May 2017: 1-6 [doi: 10.1007/s12686-017-0768-3]. 